\section{BEATA MIKOLAJCZYK}

Uniwersytet im. Adama Mickiewicza w Poznaniu, Polska

https://orcid.org/0000-0001-6421-6335
Copyright and License: Copyright by Instytut Języka Polskiego PAN, Kraków 2021. This article is published under the terms of the Creative Commons Attribution - NoDerivatives 4.0 International (CC BY- ND 4.0) License (https:// creativecommons.org/licenses/by-nd/4.0/legalcode.pl).

\title{
,STOPNIE WOJSKOWE TO NIE RZECZOWNIKI, DLATEGO TEŻ NIE MAJĄ RODZAJU"'. SOCJOLINGWISTYCZNE ASPEKTY DYSKUSJI O FEMINIZACJI STOPNI WOJSKOWYCH W NIEMCZECH
}

Słowa kluczowe: wariantywność współczesnego języka niemieckiego, socjolekt wojskowy, formy adresatywne, stopnie wojskowe, feminatywy.

\section{STRESZCZENIE}

W artykule przedstawiono analizę komentarzy internetowych odnoszących się do feminizacji rzeczowników tytularnych w ramach dyskusji, która przetoczyła się przez niemieckie media we wrześniu 2020 roku na temat planów Federalnego Ministerstwa Obrony dotyczących wprowadzenia żeńskich odpowiedników dotychczasowych stopni wojskowych. Na zebranym obszernym materiale badawczym pokazano i przedyskutowano argumenty natury społecznej oraz lingwistycznej, przy czym wskazano te, które nie dopuściły do wprowadzenia zmian planowanych odgórnie. Analiza dotyczyła relewantnych aspektów socjolingwistycznych, w tym - relacji między procesami zachodzącymi współcześnie zarówno w niemieckim społeczeństwie, jak i w języku ogólnym a rozwojem socjolektu wojskowego. Ponadto wskazano na istotne związki wartości konstututywnych dla wspólnoty wojskowej i praktyk komunikacyjnych w jej obrębie. Te zależności wpływają - z jednej strony - na wybór form językowych używanych w codziennej praktyce komunikacji w wojsku, z drugiej natomiast - determinują czynniki istotnie wpływające na rozwój socjolektu (jego form językowych oraz skryptów zachowań). W dyskusji zarysowano również historyczne determinanty stosunku do feminatywów w wojsku. Podkreślono specyfikę wspólnoty komunikatywnej, która stwarza możliwość formalnego, odgórnego wprowadzenia istotnych zmian także w rutynach językowych (jak choćby omawiana feminizacja stopni wojskowych). Przeprowadzona analiza komentarzy sformułowanych online wykazuje dużą świadomość językową członków wspólnoty wojskowej, także w odniesieniu do - trudno poddających się zmianom - skryptów zachowań. Przeprowadzona analiza pozwoliła nakreślić specyfikę funkcjonowania sytemu adresatywnego w socjolekcie wojskowym oraz sformułować wnioski na temat jej wpływu na feminizację rzeczowników tytularnych.

\footnotetext{
${ }^{1}$ Wypowiedź internauty pochodząca z korpusu badawczego: „Dienstgradbezeichnungen sind keine Substantive und haben daher auch kein Geschlecht" (SP195).
} 
We wrześniu² 2020 roku w niemieckich mediach ukazała się informacja o planach Federalnego Ministerstwa Obrony (Bundesministerium der Verteidigung) dotyczących wprowadzenia do użycia żeńskich odpowiedników dotychczasowych stopni wojskowych $(=\mathrm{SW}) \mathrm{w}$ siłach zbrojnych. W komunikacie prace nad projektem przedstawiano jako zaawansowane, a podjęcie ostatecznej decyzji miało być bardzo bliskie. Nie ujawniono jednak przy tym, jaką formę przybrałyby nowo wprowadzane feminatywy. Informowano tylko, że feminizacji poddane mają zostać wszystkie SW poza dwoma - wyjątkami miały się stać putkownik (Oberst) i kapitan (Hauptmann). Te publikacje wywołały szeroką dyskusję zarówno w samych siłach zbrojnych (Bundeswehr, pol. Bundeswera) jak i poza Bundeswerą. Stowarzyszenia zrzeszające żołnierki zainicjowały wspólną kampanię w mediach społecznościowych pod hasłem Wspólnie silne - Jesteśmy przeciw genderowaniu stopni wojskowych w Bundeswerze $e^{3}$. W dyskusję włączyli się także internauci, komentujący artykuły prasowe i wpisy zamieszone na blogach.

Dyskusję toczącą się w mediach zakończono w siłach zbrojnych - już 16 września 2020 roku - wpisem na Twitterze. Sekretarz stanu w ministerstwie obrony poinformował w nim o (przynajmniej czasowej) rezygnacji z realizacji - jak się okazało - bardzo kontrowersyjnego projektu.

\section{CEL BADANIA I KORPUS BADAWCZY}

W artykule przedstawiono socjolingwistyczną analizę komentarzy internetowych zamieszczonych przez czytelników jako reakcję na artykuły dotyczące wspomnianych planów genderyzacji SW, opublikowane online. Autorce przyświecał następujący cel: analiza ma przybliżyć współczesne postrzeganie społeczne w Niemczech kwestii związanych z językiem i jego użyciem oraz zmianami zachodzącymi w nim obecnie, w tym zwłaszcza - jego feminizacji. Tak sformułowany cel dotyka zarówno charakteru samych zmian (gramatycznych, komunikacyjno-pragmatycznych itd.), jak i procesów do nich prowadzących (przede wszystkim wpływu zjawisk, które zachodzą w społeczeństwie na zjawiska językowe). W niniejszym artykule uwagę skierowano na jeden z wariantów współczesnego języka niemieckiego - socjolekt wojskowy, a analizie poddano wybrane jego cechy. Jednak dyskusja na temat wprowadzenia żeńskich stopni wojskowych wpisuje się w zdecydowanie szerszą debatę dotyczącą procesu feminizacji języka ogólnego. W niniejszej pracy należy zatem ustalić - po pierwsze - jakie argumenty z dyskusji „ogólnych" okazują się relewantne w dyskusji o feminatywach w komunikacji wojskowej, a po drugie - co wyróżnia w tej kwestii socjolekt wojskowy, a może być przyczyną hamowania przyjęcia żeńskich rzeczowników tytularnych służących jako SW, mimo że feminizacja tytułów to proces konsekwentnie postępujący w języku niemieckim.

\footnotetext{
${ }^{2}$ Większośc mediów poinformowała o tym po raz pierwszy 11 września.

${ }^{3}$ Gemeinsam stark - wir sind gegen das Dienstgradgendering in der Bundeswehr. Wszystkie przykłady przytoczono w moim tłumaczeniu na język polski. Oryginalne teksty zamieszczam w przypisach dolnych.
} 
Prezentacja tej wewnątrzniemieckiej dyskusji, w której centrum znajduje się współczesna niemczyzna, jest nie bez znaczenia dla czytelnika polskiego - to właśnie polscy językoznawcy i publicyści czy blogerzy w debatach dotyczących feminatywów w języku polskim często powołują się na przykład niemiecki (Bąk 2010, 2013; Cieszkowski 2015; Dargiewicz 2021; Łaziński 2006; Miodek 2010). Z jednej strony wskazują na specyfikę strukturalną języka niemieckiego, ułatwiającą mu ,przyjmowanie” rzeczowników tytularnych rodzaju żeńskiego, z drugiej natomiast przywołują debatę publiczną dotyczącą feminatywów, czy też - szerzej - języka inkluzywnego, toczącą się w Niemczech nieprzerwanie od lat 70. XX wieku. Specyfika słowotwórcza rzeczowników powoduje silne wykorzystywanie we współczesnym języku niemieckim mocji, czego skutkiem stało się powstanie i używanie w komunikacji (zarówno w sytuacjach oficjalnych, jak i w nieoficjalnych), licznych żeńskich nazw zawodów, funkcji czy tytułów. Dlatego z perspektywy obserwatora polskiego dyskursu dotyczącego feminatywów zdecydowanie silniejsza zdaje się akceptacja dla procesów genderyzacji języka w społeczeństwie niemieckim, czemu wyraz dają poniższe wypowiedzi:

Żadnego problemu nie mają Czesi i Słowacy, którzy tradycyjnie operują przyrostkowymi wykładnikami żeńskości i tworzą formacje typu rektorka [...] - tak jak w codziennym oficjalnym i nieoficjalnym obiegu języka niemieckiego - typologicznie stabiej przecież eksponującego rodzajowość gramatyczna niż języki słowiańskie - znajdują się Kanzlerin, Ministerin, Rektorin, Dekanin, Professorin z przyrostkiem -in - odpowiednikiem naszego -ka (kanclerka, ministerka, rektorka, dziekanka, profesorka) (Miodek 2010 w Gazecie Wrocławskiej).

Doskonale poradzili sobie z tą kwestią Niemcy: wiele eksponowanych stanowisk i zawodów ma formę żeńską, są więc w niemieckim profesorki, magisterki i inżynierki. (Jasińska, blog, Język i kropka, data opublikowania nieustalona).

Warto zatem podjąć próbę socjolingwistycznej interpretacji debaty, skoro cała ta dyskusja doprowadziła do zablokowania zmian, ,z którymi doskonale poradzili sobie [...] Niemcy" w innych obszarach komunikacyjnych - aby odpowiedzieć na pytanie, jakie czynniki okazały się w niej relewantne.

Analizie poddano komentarze internetowe, a ich wybór motywowała chęć przedstawienia opinii szerokiej grupy obywateli. Treści publikowane $\mathrm{w}$ internecie docierają do bardzo szerokiego kręgu odbiorców, a funkcja komentarza daje użytkownikom sieci możliwość - często szybkiej i spontanicznej - reakcji. Internauci wyrażają w ten sposób swoje opinie, kreślą własne stanowisko, często także dają przy okazji wyraz emocjom. Publikowanie komentarzy można uznać za jedną z form partycypacji społecznej, realizowaną poprzez publiczne wyrażanie swojego zdania w środowisku cyfrowym.

Na potrzeby niniejszego badania wybrano komentarze do trzech publikacji medialnych z 11 września 2020 roku. Materiał obejmuje 1023 komentarze, a w jego skład wchodzą wpisy będące reakcją na następujące artykuły:

- „Verteidigungsministerium plant weibliche Dienstgrade bei der Bundeswehr”; opublikowany na portalu www.spiegel.de - 711 komentarzy, poniżej oznaczonych symbolem SP; 
- „Bundeswehr soll weibliche Dienstgrade bekommen”; opublikowany na portalu www.zeit.de - 181 komentarzy, poniżej oznaczonych symbolem Z;

- „Frau Hauptmann bleibt, Frau Oberst auch”; - opublikowany na blogu Augen geradeaus - 131 komentarzy, poniżej oznaczonych symbolem AA.

Wybrano portale internetowe dwóch opiniotwórczych periodyków niemieckich, a także blog adresowany do obecnych i byłych żołnierzy oraz do osób zainteresowanych wojskowością. Taki wybór umożliwił uwzględnienie opinii „,szerokich kręgów czytelników”, również tych aktywnych w środowisku wojskowym. Jedną z cech komentarzy internetowych jest anonimowość ich autorów, jednak w badanym materiale nadawcy komunikatów bardzo często podawali informacje pozwalające identyfikować ich jako byłych lub obecnych członków społeczności wojskowej. Tak zebrany materiał można wstępnie scharakteryzować następująco: nie wystąpiły istotne różnice merytoryczne między komentarzami zamieszczonymi w trzech źródłach internetowych w zakresie prezentowanych treści. Trudno przypisać użytkownikom jednego z nich inne poglądy w stosunku do pozostałych. Osoby komentujące wypowiedziały się w przeważającej większości przeciwko używaniu żeńskich form SW, a przytaczane argumenty pojawiały się porównywalnie często na wszystkich trzech forach.

$\mathrm{Z}$ bardzo licznych argumentów różnej natury w poniższym opracowaniu wybrano tylko te najbardziej reprezentatywne i dominujące w dyskursie.

\section{FEMINIZACJA STOPNI WOJSKOWYCH A PROCES GENDERYZACJI JĘZYKA OGÓLNEGO I INNE ZJAWISKA SPOLECZNE}

Próba feminizacji SW nie dzieje się w społecznej próżni, także respondenci widzą ścisły związek proponowanych zmian językowych w komunikacji wojskowej z procesami, które od dawna zachodzą w języku niemieckim i komunikacji, zwłaszcza w sytuacjach formalnych. Uznają feminizację SW za kolejny etap postępującej genderyzacji języka i traktują propozycję ministerstwa jako pochodną ogólnospołecznej tendencji do wprowadzania ,języka równościowego". Sami w większości generalnie się z tą tendencją nie zgadzają, ponieważ uznają ją za szkodliwą dla języka przede wszystkim z powodu wprowadzania form, które powodują narastającą kompleksowość struktur językowych. W ich opinii stosowanie takich technik języka inkluzywnego, jak splitting, symbole graficzne, najczęściej tzw. gwiazdki (np. Lehrer*in), prowadzi do powstawania tekstów mało czytelnych oraz zakłóca ich recepcję.

(1) Ze względu na procesy zachodzące w społeczeństwie itd. można zrozumieć pomysł ministerstwa, ale jest on całkowicie chybiony. Doprowadzi w niedługim czasie do tego, że nowe nazwy będą wyśmiewane. [...] Ale koleżanki, z którymi rozmawia się na ten temat, cóż, one nie chcą tego wszystkiego.

\footnotetext{
${ }^{4}$ We współczesnej niemczyźnie stosuje się liczne techniki zapisu rzeczowników w liczbie mnogiej wskazujące na ich odniesienie zarówno do kobiet, jak i do mężczyzn: Lehrerin/-innen, LehrerInnen, Lehrer*innen, Lehrer_innen, Lehrer:innen, Lehrer(innen). (por. DUDEN-Handbuch geschlechtergerechte Sprache 2020).
} 
To jest po prostu „dyskryminujące” $i$,,śmieszne”. W moim (żeńskim) otoczeniu akceptacja jest bliska zeru $^{5}($ AA40).

(2) Potrzebne jest wsparcie kobiet przy przeciwdziałaniu temu wszechobecnemu zepsuciu języka. [...] Istnieją już pozbawione wszelkiej logiki i całkowicie niekonsekwentnie napakowane gwiazdkami produkty prasowe i strony internetowe w zdeformowanej nowomowie, których nie mogę już czytać, ponieważ po prostu nie mogę skupić się na treści ${ }^{6}$ (SP193).

Ponadto zmiany zachodzące w języku są - zdaniem autorów komentarzy - inicjowane i wyczekiwane przez wąskie grupy osób zaangażowanych, których wysiłki ocenia się często jako polityczne czy ideologiczne.

(3) I kto tego wyczekiwał? Osoby zainteresowane podobno nie. A więc pewnie zawodowe feministki spoza sił zbrojnych $[\ldots]^{7}$ (AA64).

(4) Co się tyczy języka „równościowego”, to mam wrażenie, że jest to przede wszystkim sprawa kilku feministek oraz pełnomocniczek ds. równouprawnienia kobiet. Właściwie nie znam kobiety, która w życiu codziennym uznawałaby to za problem ${ }^{8}$ (SP118).

Kwestie związane z feminizacją języka są przedstawiane jako obce zarówno im samym, jak i ich otoczeniu, a okazują się istotne - w ich mniemaniu - jedynie w środowisku akademickim oraz w mediach. Dotyczą zatem elit. Sami odczuwają te zmiany jako napływające do ich środowiska z zewnątrz. Komentujący mają poczucie, że wąska grupa, w tym przypadku - decydentów, chce narzucić im przyjęcie pewnych zmian językowych, które nie ukształtowały się w ewolucyjnym procesie rozwoju języka, lecz powstały przy biurkach ,ideologów”. Z genderyzacją języka trudno im dyskutować lub być wobec niej sceptycznym, gdyż stała się ona elementem politycznej poprawności.

(5) To szaleństwo związane z językiem równości płci ma miejsce tylko w salach wykładowych i mediach. Jest to - jak przy reformie ortografii - zmiana języka narzucona z góry, a nie - rewolucja oddolna ${ }^{9}$ (SP218).

${ }^{5}$ „Auf Grund der Gesellschaftlichen Entwicklungen etc. kann man die Idee des BMVg verstehen, aber sie ist eindeutig falsch. Es führt unlängst dazu, das wahrscheinlich diese neuen Bezeichnungen ins Lächerliche gezogen werden. [...] Aber mit den weiblichen Kameraden, mit denen man über das Thema spricht, nun, sie wollen das Ganze nicht. Es ist einfach «diskriminierend» und «lächerlich». In meinem Umfeld (weiblich) geht die Akzeptanz gegen Null".

${ }^{6}$ „Es braucht die Unterstützung der Frauen, dieser allgegenwärtigen Sprachverhunzung entgegenzutreten. [...] Es gibt schon einige bar jeder Logik und völlig inkonsequent mit Sternchen vollgepatschten Presseerzeugnisse und Internetseiten in deformiertem Neusprech, die ich nicht mehr lesen kann, ohne ständig vom Inhalt abgelenkt zu sein".

${ }^{7}$ „Wer hat denn darauf gewartet? Die Betroffenen dem Vernehmen nachnicht. Also wohl Berufs-Feministinnen außerhalb der Streitkräfte [...]”.

${ }^{8}$ „Mein Eindruck bei der «geschlechtergerechten» Sprache ist schon der, dass dies in erster Linie ein Ding von ein paar Feministinnen und Frauenbeauftragten ist. Im Alltag kenne ich tatsächlich keine Frau die es als Problem sieht".

${ }^{9}$ „Dieser Gendersprachwahnsinn findet nur in Hörsälen und in den Medien statt. Es ist -- wie bei der Rechtschreibreform -- verordneter Sprachwandel von oben und eben keine Graswurzelrevolution von unten". 
(6) Oczywiście, język niemiecki żyje i ciągle się zmienia. Przeciwnikom genderowego psucia języka insynuuje się regularnie, że są politycznymi konserwatystami i najchętniej zabetonowaliby język niemiecki. To jest, przynajmniej w moim przypadku, kompletna bzdura. Bronię się właściwie jedynie przed tym dlatego, że radykalna mniejszość z powodów politycznych chce narzucić nową ortografię lub gramatykę. Jestem rozczarowany niemiecką lingwistyką, bo nie sprzeciwia się temu, że żyjący język wymyślany jest na nowo „na desce kreślarskiej”10 (SP460).

Internauci wskazują także na - w ich mniemaniu - znikomą wagę problemu. Nie zauważają korelacji między procesami dokonującymi się w społeczeństwie a zmianami zachodzącymi w języku i komunikacji lub nie widzą potrzeby utrwalania tych zmian w języku. Uznają wprowadzenie żeńskich SW za zmiany kosmetyczne, zabawę lub mało istotny lifting.

(7) To bardzo ciekawe, że dowództwo uprawia kosmetykę językową, a zainteresowani chcieliby czegoś sensownego ${ }^{11}$ (SP155).

(8) No tak, nowe etykiety są tanie, nowe wyposażenie jest drogie ${ }^{12}$ (SP190).

Ponadto komentujący podkreślają błahość kwestii językowej w stosunku do innych problemów, z jakimi zmagają się siły zbrojne. Próbę feminizacji SW traktują jako zasłonę dymną odwracającą uwagę społeczną od faktu, że władze nie potrafią rozwiązać prawdziwych problemów wojska.

(9) Mamy już nazwy stopni wojskowych. To jest moim zdaniem czysty manewr odwracający uwagę ewentualnie próba zaistnienia i nic innego jak jawne marnotrawstwo czasu i energii ${ }^{13}$ (AA11).

(10) Nasi żołnierze (m/ż/n) byliby szczęśliwi, gdyby mieli odpowiednie wyposażenie osobiste. Kamizelki, buty itd. Na tym skupiają się żołnierze [...]. Ale to kosztuje;) Zmiana języka - nie;) ${ }^{14}$ (AA33).

\section{FEMINIZACJA STOPNI WOJSKOWYCH A WOJSKOWA WSPÓLNOTA KOMUNIKATYWNA}

Socjolekt wojskowy, będący przedmiotem tej pracy (por. Grabias 2019, 99) stanowi jedną z odmian współczesnego języka niemieckiego z charakterystycznym dla niej zasięgiem

${ }^{10}$ „Natürlich lebt die deutsche Sprache, und sie wandelt sich ständig. Gegnern der Gendersprachverhunzung wird regelmäßig unterstellt, sie seien politisch Konservative und wollten Deutsch wohl am liebsten in Beton gießen. Das ist, zumindest in meinem Fall, kompletter Unsinn. Ich wehre mich lediglich dagegen, wenn eine radikale Sprachminderheit der Mehrheit aus politischen Gründen eine neue Rechtschreibung oder Grammatik verordnen will. Ich bin hier auch enttäuscht von der deutschen Linguistik, die offenbar keine Einwände dagegen hat, wenn eine lebendige Sprache am Reißbrett neu entworfen werden soll”.

${ }^{11}$ „Sehr interessant dass die Führung Sprachkosmetik betreibt und die Betroffenen lieber Sinnvolles hätten”.

${ }^{12}$ „Ja, neue Etiketten sind billig, neue Ausrüstung ist teuer”.

${ }_{13}$ „Wir haben bereits funktionierende Dienstgradbezeichnungen. Das ist m.E. ein reines Ablenkungsmanöver bzw. der Versuch sich mal wieder ins Gespräch zu bringen und nichts anderes als eine reine Verschwendung von zeit und Energie".

${ }^{14}$ „Unsere Soldaten (m/w/d) wären glücklich, wenn sie eine adäquate pers. Ausrüstung hätten. Westen, Schuhe, etc. Das ist der Schwerpunkt in der Truppe [...]. Aber der Kostet;) Veränderung der Sprache nicht;)”. 
użycia w postaci szeroko pojętego środowiska wojskowego. Można go zaklasyfikować do zbioru wariantów zawodowych. Jego użytkownikami są żołnierze oraz osoby cywilne, które zgodnie z obowiązującymi regulacjami prawnymi są zatrudnione w armii zawodowej. Jednak dla członków wspólnoty wojskowej bycie żołnierzem (Marcinkowski 2014) to nie tylko aktywność zawodowa, lecz także służba daleko wykraczająca poza ramy „zwykłego” zawodu, traktowana często w kategoriach powołania. A środowisko wojskowe to grupa mająca swój etos i kodeks honorowy. Wspólnota wojskowa opiera się na fundamencie służby dobru wspólnemu (służba społeczeństwu i obrona ojczyzny) dzięki licznym wartościom, takim jak patriotyzm, miłość do ojczyzny, gotowość do poświęceń w jej obronie czy tradycja, a także solidarność zawodowa, czyli poczucie silnej wewnętrznej więzi pomiędzy wojskowymi, wzajemne zaufanie i szacunek oraz duma z przynależności do tej wspólnoty. Na takich podstawach aksjologicznych konstytuuje się silnie związane z sobą środowisko z wewnętrznymi zasadami oraz rytuałami. Te związki wykraczają daleko poza ramy czysto zawodowych. Do najbardziej oczywistych pozajęzykowych wyróżników tej wspólnoty należą mundur oraz używane znaki graficzne - symbole i emblematy poszczególnych sił zbrojnych, sztandary jednostek itd. Rzecz jasna, czynnikiem wyróżniającym to środowisko jest również język, a komunikacja językowa okazuje się powiązana z użyciem ukształtowanych historycznie kodów niejęzykowych (np. salutowanie), a także innych znaków, takich jak oznaczenia SW na pagonach itp. Socjolekt wojskowy łączy zatem znamiona zarówno języków zawodowych, jak i środowiskowych. Dlatego należy go uznać za odmianę środowiskowo-zawodową, a na plan pierwszy wysunąć wartości łączące członków wspólnoty komunikatywnej, jednak bez pomijania cech specyficznych dla komunikacji w sytuacjach zawodowych (por. Kołodziejek 2010; Markowski 1992).

Jak każda odmiana grupowa, ten wariant ma dychotomiczny wymiar społeczny: z jednej strony łączy i identyfikuje komunikacyjnie członków wspólnoty wojskowej, a z drugiej - został przez tę wspólnotę stworzony w procesie historycznym i dzięki niej ewoluuje (por. Piekot 2008; Grabias 2019). Tradycja i ciągłość stanowią dla wojskowej wspólnoty komunikatywnej podstawowe wartości i to do nich przede wszystkim odwołują się internauci apelujący do ministerstwa o zaniechanie planów. SW jako znaki językowe ukształtowane wraz z ewolucją samych sił zbrojnych są dla tych osób nośnikiem ważnych wartości. Należy podkreślić w tym kontekście fakt, że sytuacja Bundeswery jest szczególna (i to jest także oczywiste dla respondentów), gdyż nie jest ona bezpośrednią kontynuatorką niemieckiej armii z lat wcześniejszych. Nie chce i nie może czerpać z niej ani wzorców, ani tradycyjnych wartości. SW są zatem dla obecnych żołnierzy jednym z niewielu tradycyjnych symboli, które należy chronić i nie dopuścić do ingerowania w ich formę. Oznaką poszanowania żołnierzy, ich służby, będzie pozostawienie ważnych i drogich im symboli. Za to wprowadzenie zmian w systemie SW postrzega się jako pozbawienie wojska honoru i powagi.

(11) Tradycja jest dla nas ważnym elementem w definiowaniu naszej tożsamości jako żołnierzy [...]. Nasze stopnie wojskowe są jedną z niewielu tradycji Bundeswery i jestem pewien, one będą dobrze 
nam służyły aż do powstania armii europejskiej, a wtedy, mam nadzieję, znajdziemy wspólne europejskie, neutralne płciowo nazwy. [...] Są jeszcze żołnierze (m/ż), dla których na pierwszym miejscu jest „służba” i „koleżeństwo"15 (AA111).

(12) Z tradycją mamy raczej problemy, a teraz odbiera się nam nasze od wielu lat istniejące stopnie wojskowe. Zawód żołnierza nie jest przecież zawodem jak każdy inny, wszyscy złożyliśmy przysięgę, przyrzeczenie, że będziemy bronić naszego kraju także kosztem życia. Gdyby wreszcie w naszym kraju z należytym uznaniem i właściwym szacunkiem traktowano zawód żołnierza [...], wtedy nie powstałby taki bezsensowny pomysł $[\ldots]^{16}$ (AA112).

Podstawowym czynnikiem rzutującym na kształt danego wariantu językowego jest, oczywiście, jego wspólnota komunikatywna. Wojsko to tradycyjnie i historycznie środowisko męskie, choć w historii wojskowości nie brakuje przykładów na zaangażowanie kobiet (por. Carreiras i Kümmel 2008). Także siły zbrojne powstałe w Republice Federalnej Niemiec w latach 1955-1956 były początkowo strukturą właściwie całkowicie męską. Zapisy ustawy zasadniczej (par. 12a, ust. 4), obowiązujące od 1956 roku, zabraniały kobietom służby wojskowej z bronią w ręku. W 1975 roku stworzono kobietom możliwość służby wojskowej w korpusie medycznym, a w 1989 roku zaczęto przyjmować je do orkiestr wojskowych. Służba w innych formacjach była dla nich nadal niedostępna. Do zmian przyczynił się dopiero spór prawny jednej z kandydatek do służby wojskowej, która wyrażała chęć i była - zgodnie ze swym wykształceniem - przygotowana do służby w jednostce technicznej. Proces doprowadził w 2000 roku do wydania przez Europejski Trybunał Sprawiedliwości nakazu zmiany niemieckiej konstytucji, właśnie w punkcie 12a, ust. 4. Obecne brzmienie tego paragrafu przyjęte 19 grudnia 2000 roku zakazuje zmuszania kobiet do służby z bronią w ręku, jednak mogą się one do niej zgłaszać dobrowolnie. W styczniu 2001 roku wcielono do wojska 253 ochotniczek, pod koniec tego roku służbę wojskową odbywało już 6700 kobiet, a w kolejnych latach ta liczba systematycznie rosła. Rok 2004 przyniósł uchwalenie ustawy o zrównaniu w prawach kobiet i mężczyzn wykonujących zawód żołnierza (Gesetz zur Gleichstellung von Soldatinnen und Soldaten der Bundeswehr). Kobiety w wojsku stanowiły we wrześniu 2020 roku (wszystkie dane liczbowe pochodzą z oficjalnego serwisu informacyjnego Bundeswery, por. www.bundeswehr.de) ok. 12-procentową grupę żołnierzy. Pośród ok. 183 tys. żołnierzy służy 22800 kobiet, z czego 6100 ma stopień oficerski. Żołnierki odbywają służbę we wszystkich rodzajach wojsk i na wszystkich stanowiskach, służą

${ }^{15}$ „Tradition ist für uns ein wichtiges Element in der Definition unserer Identität als Soldaten [...]. Unsere Dienstgrade sind eines der wenigen Bw Traditionen und ich bin mir sicher, bis zu einer EU-Armee leisten diese uns gute Dienste und dann werden wir hoffentlich einheitliche, europäische geschlechtsneutrale, Bezeichnungen finden. [...] Es gibt eben Soldaten $(w / m)$ für welche der «Dienst» und die «Kameradschaft» an erste Stelle steht".

${ }^{16}$ „Mit der Tradition tun wir uns ja eh schon schwer und jetzt nimmt man uns auch noch unsre langjährigen Dienstgrade. Der Soldatenberuf ist eben kein Beruf wie jeder andere, wir haben alle einen Eid, einen Schwur geleistet für unser Land mit unserem Leben einzustehen. Würde man den Soldatenberuf [...] auch in unserem Land endlich mal mit der nötigen Anerkennung und dem würdigenden Respekt behandeln [...] dann gäbe es solch sinnfreie Idee gar nicht erst [...]". 
zarówno w kraju, jak i na zagranicznych misjach wojskowych. Ich obecność stała się dla niemieckich sił zbrojnych codziennością.

Internauci mają świadomość tych historycznych zmian, chętnie podkreślają jednak pierwotnie męski charakter wojska oraz to, że kobiety - jako te, które zwyczajów wojskowych nie tworzyły - powinny się przystosować do zasad i form komunikacyjnych uprzednio ukształtowanych.

(13) Pani kapitanka brzmi w moich uszach dość absurdalnie. Albo pani poruczniczka. Też raczej głupio. [...] Żołnierki pełnią służbę w męskim świecie, powinno zostać pani kapitan ${ }^{17}$ (SP412).

Próba wprowadzenia żeńskich SW to - według opinii internautów - manewr, który ma przesłonić fakt, że w wojsku nie ma jak dotąd prawdziwego równouprawnienia. Sam zabieg językowy nie zastąpi innych decyzji prowadzących do równego traktowania kobiet i mężczyzn. Feminizacja języka nie usprawiedliwi braku działań ułatwiających kobietom służbę w wojsku, polegających na zagwarantowaniu im np. właściwego wyposażenia lub odpowiedniego traktowania.

(14) Byłoby lepiej, gdyby zlikwidowano bariery istniejące, dotyczące czy to wyposażenia, czy to nastawienia niektórych przełożonych. Jeśli w tym obszarze rzeczywiście jest potrzeba równouprawnienia, to dotyczy to ustawy zasadniczej, która zakłada obowiązkową służbę wojskową nadal tylko dla mężczyzn. Jeśli równouprawnienie, to bardzo proszę całkowite ${ }^{18}(\mathrm{Z} 96)$.

Wojsko to wspólnota, w której wszyscy mają takie same prawa, ale każdy powinien sprostać tym samym wymaganiom. Tak autorzy komentarzy definiują prawdziwe równouprawnienie. Wyrażają obawę, że feminizacja SW może prowadzić do osiągnięcia odwrotnego celu, będzie podkreślała różnice oraz stanie się powodem dyskryminacji żołnierek.

(15) Myślę, że tą historią wyrządzimy kolejną krzywdę naszym koleżankom. Nasza armia żyje z tego, że wszyscy są równi, a różnice schodzą na drugi plan. Dla mnie na szczęście nic się nie zmieni, tak czy tak. Ale szkoda mi koleżanek, które stracą ciężko wypracowany stopień, a inni zwracać się do nich będą za pomocą negatywnie konotowanej wersji mojego stopnia wojskowego. [...] Nie powinniśmy podkreślać różnic, ale podobieństwa, które pomogłyby w tej sprawie ${ }^{19}$ (AA48).

${ }^{17}$ „Eine Frau Hauptmännin klingt in meinen Ohren ziemlich abstrus. Oder Frau Leutnantin. Auch eher albern. [...] Die Soldatinnen leisten einen ihren Dienst in einer Männerwelt und man sollte es bei Frau Hauptmann belassen".

${ }^{18}$ „Besser wäre es, bestehende Benachteiligungen in der Truppe zu beseitigen, sei es bei der Ausrüstung oder bei den Einstellungen so mancher Vorgesetzten. Wenn es auf einem Gebiet überhaupt eine Angleichung bedarf, dann ist es im Bereich des Grundgesetzes, was den Wehrdienst als Wehrpflicht noch immer nur Männer einschließt".

${ }^{19}$ Ich denke wir werden mit dieser Geschichte unseren weiblichen Kameraden einen weiteren Bärendienst erweisen. Unsere Armee lebt davon, dass alle gleich sind und Unterschiede in den Hintergrund treten. Für mich selbst wird sich zum Glück nichts ändern, so oder so. Mir tun aber die Kameraden leid, die ihren hart erarbeiteten Dienstgrad verlieren und nur noch mit einer negativ belegten Versionen meines Dienstgrades angesprochen werden. [...] Wir sollten nicht Unterschiede betonen sondern Gemeinsamkeiten, das wäre der Sache dienlich! 
(16) [...] genederowanie w wojsku wyostrza różnice, które inaczej nie byłyby zauważalne. Każdy wykonuje pracę związaną ze swoim stanowiskiem niezależnie od płci ${ }^{20}$ (AA98).

Bardzo wiele głosów w dyskusji akcentuje konieczność wysłuchania opinii kobiet-żołnierzy, a towarzyszy temu sugestia, że ich zdanie powinno być wiążące dla władz. Liczni respondenci, zwłaszcza - komentujące żołnierki, wyrażają silny protest wobec ujawnionych planów. Boją się, że w wyniku feminizacji SW dojdzie do nie tylko nierównego traktowania przez innych, lecz także do utraty (także we własnym odczuciu) prestiżu swoich stanowisk i uznania swoich dotychczasowych dokonań zawodowych. Obawiają się również obniżenia własnego statusu w środowisku, zwłaszcza że na osiągnięcie swojej pozycji musiały ciężko zapracować. Byłoby to istotnym zaburzeniem funkcji honoratywnej SW (funkcjom form adresatywnych poświęcono dalsze części artykułu).

(17) Czy większość żołnierek wypowiedziała się za „feminizacją” ich stopni wojskowych? (ponieważ dotyczy to żołnierek, z pewnością były o to pytane! Czy też nie?) Postrzegałabym taką „reformę języka” jako deprecjację żołnierek ${ }^{21}$ (SP565).

(18) Jestem od ponad 18 lat żołnierką w siłach zbrojnych i podobnie jak musiałyśmy wywalczyć sobie dostęp do wszystkich obszarów [wojska], tak musiałyśmy wywalczyć sobie szacunek i uznanie nas za równe naszym kolegom. Byłam jako podoficer sztabowy, żeński (ż), tak nas wtedy określano, jedną z pierwszych kobiet w oddziale bojowym i wiem dokładnie, o czym mówię, gdy chodzi o to, jak ciężką pracą pozyskać i wywalczyć szacunek i uznanie. [...] Ale feminizacja stopni wojskowych nie ma zupełnie nic wspólnego z równouprawnieniem. Jako żołnierka czujesz się nie tylko pozbawiona honoru, ale także wyśmiana ${ }^{22}$ (AA112).

\section{FEMINIZACJA STOPNI WOJSKOWYCH A FUNKCJE FORM ADRESATYWNYCH}

Język wojskowych powstał i ewoluuje wraz z pojawieniem się i rozwojem wojska. Ma całą paletę historycznie ukształtowanych bardzo lub mniej sformalizowanych i zrutynizowanych zachowań komunikacyjnych (np. komend, meldunków) i struktur gramatycznych dla nich typowych. Do tego zbioru należy bez wątpienia sposób zwracania się żołnierzy do siebie. System adresatywny niemieckiego socjolektu wojskowego nie znalazł jeszcze lingwistycznego opracowania. To spory deficyt badawczy, gdyż sposób zwracania się

${ }^{20}$, ,[... [ gendern in der Truppen verdeutlich Unterschiede, die sonst nicht auffallen würden. Jeder macht die Arbeit, die zu seinem Dienstposten gehört, unabhängig vom Geschlecht.

${ }^{21}$ „Hat sich eine Mehrheit der Soldatinnen für ein «Gendering» ihrer Dienstgrade ausgesprochen ? (da es die Soldatinnen betrifft, wurden sie doch bestimmt dazu befragt ! Oder etwa nicht ?). Würde so eine «Sprachreform» eher als eine Herabwürdigung der Soldatinnen ansehen".

${ }^{22}$ „ICh bin seit über 18 Jahren Soldatin in den Streitkräften und so, wie wir uns den Zugang zu allen Bereichen erkämpfen mussten, mussten wir uns auch den Respekt und die Anerkennung, unseren männlichen Kameraden ebenbürtig zu sein, erkämpfen. Ich war als Stabsunteroffizier, weiblich (w), so wurde dies damals bezeichnet eine der ersten Frauen in eine Kampfstaffel und ich weiß genau, wovon ich rede, wenn es darum geht, sich Respekt und Anerkennung schwer erarbeiten und erkämpfen zu müssen. [...] Aber das Gendern der Dienstgrade hat rein gar nichts mit Gleichstellung zu tun. Als Soldatin fühlt man sich nicht nur seiner Ehre beraubt, sondern zusätzlich verspottet [...]". 
żołnierzy do siebie jest dla ich socjolektu istotnym wyróżnikiem. Oczywiście, wyróżnia się on formą, ale także swoją funkcją pragmatyczną. Działalność wojska charakteryzują przecież silna kolegialność oraz konieczność efektywnej współpracy i ścisłej koordynacji oraz precyzji działań, a odpowiednie adresowanie wypowiedzi do innych ma istotny udział w skutecznej komunikacji (i kooperacji) nie tylko w obrębie grupy ludzi, lecz także między poszczególnymi jednostkami organizacyjnymi / grupami w ramach silnie zhierarchizowanej i skomplikowanej struktury organizacyjnej, jaką są siły zbrojne.

Specyfiką wojska okazuje się ścisła kodyfikacja - wzajemnie zwracanie się do siebie, pozdrawianie i oddawanie honorów to zjawisko sformalizowane oraz wysoce zrytualizowane i zrutynizowane. Nie podlega jednostkowym decyzjom poszczególnych użytkowników języka. Zostało im narzucone w postaci regulaminów. Te rutyny komunikacyjne są automatyzowane poprzez odpowiednie ćwiczenia podczas musztry już w czasie szkolenia wstępnego. Regulamin ogólny sił zbrojnych (Allgemeine Dienstvorschriften für das Bundesheer) nakazuje żołnierzom w kontaktach służbowych zwracać się do siebie z wykorzystaniem złożonego zwrotu adresatywnego składającego się z formy pan/pani i stopnia wojskowego oraz (fakultatywnie podanego) nazwiska.

Łaziński $(2006,244)$ twierdzi, że nominalne formy adresatywne w większości identyfikują płeć adresata wypowiedzi. SW - gdy stają się składnikami złożonych form adresatywnych - nie należą do elementów językowych identyfikujących płeć. Z punktu widzenia niemieckiej gramatyki są rzeczownikami rodzaju męskiego. Ten język nie znastosowanej w języku polskim w tym celu - blokady fleksyjnej rzeczowników męskich odnoszących się do kobiet (z pania sierżant, a nie $-z$ pania sierżantem). W zwrocie adresatywnym określonym $\mathrm{w}$ regulaminie to formy pan/pani przejmują funkcję znacznika płci (por. np. Bąk 2010).

Formy adresatywne pełnią w komunikacji wiele funkcji, a na ich czele należy postawić dwie: funkcję deiktyczną oraz funkcję honoratywną. Marcjanik $(2001,33)$ postrzega formy adresatywne jako ,grzecznościową obudowę” innych aktów mowy, mającą na celu wyrażanie szacunku dla interlokutora. Ta funkcja w sposób bardzo silny wpisuje formy adresatywne w specyfikę socjolektu wojskowego. Ich użycie w środowisku wojskowym nie jest - jak to dzieje się w wielu innych sytuacjach poza siłami zbrojnymi - jedynie przejawem dobrego wychowania. Wspólnota wojskowa opiera się przecież - z jednej strony - na silnym zhierarchizowaniu, a z drugiej - na szacunku do swoich członków, zwłaszcza do dowódców, przełożonych i starszych stopniem. Jednym z obowiązków żołnierza jest oddawanie szacunku rozmówcom, także przez właściwe zwracanie się do nich. Z funkcją honoratywną w ścisły sposób związane są funkcje relacyjna oraz nominacyjna. Formy adresatywne stanowią ważne werbalne wykładniki relacji społecznych, ich funkcja relacyjna polega na ustanawianiu i oznaczaniu przy pomocy środków językowych typu relacji społecznej zachodzącej między uczestnikami komunikacji. To one zaznaczają stopień dystansu między rozmówcami, szczególnie istotny w tak hierarchicznie zbudowanej społeczności jak wojsko. Funkcja nominacyjna jest realizowana poprzez przypisanie odbiorcy do odpowiedniej grupy społecznej (np. do grupy przełożonych, ale także do grupy mężczyzn lub kobiet). Niezwykłe znaczenie dla skuteczności 
komunikacji, zwłaszcza w warunkach ekstremalnych (np. bojowych), trzeba przypisać funkcji deiktycznej SW. To ich właściwe użycie pozwala na jednoznaczne wskazanie odbiorcy wypowiedzi w - często niezwykle trudnej i stresującej, a przez to negatywnie wpływającej na percepcyjne możliwości odbiorcy - sytuacji komunikacyjnej, a zarazem staje się gwarancją właściwego, jednoznacznego i szybkiego odczytania komunikatu przez odbiorcę, do którego został on wystosowany.

$\mathrm{W}$ analizowanym materiale badawczym można odnaleźć wiele uwag, których interpretacja lingwistyczna prowadzi nas do stwierdzenia, że dla dobrej komunikacji w środowisku wojskowym szczególnie relewantne są funkcje nominacyjna oraz deiktyczna SW.

$\mathrm{Z}$ argumentów przytaczanych przez internautów wynika, że postrzegają oni funkcję nominacyjną SW jako wykładnik przynależności do grupy osób znajdujących się w pewnej pozycji zawodowej. Natomiast zadaniem SW nie jest określanie przynależności do grupy kobiet lub mężczyzn, gdyż taka indywidualna cecha osobowa nie ma wpływu na wykonywanie zadań przynależnych pozycji. Dostrzegamy tu socjolektalne zredukowanie zakresu funkcji nominacyjnej SW. Konsekwencją takiego spojrzenia jest wyrażona w komentarzach - konieczność utrzymania jednej formy SW w odniesieniu do przedstawicieli obu płci.

(19) Czy ktoś kiedyś to zrozumie. Nazwy zawodów czy stopni oznaczają POZYCJĘ. Ona jest tylko obsadzona przez osobę. Zadaniem pozycji jest charakterystyka związanych z nią czynności, a nie płci zajmującej ją osoby. W innych językach jest to często bardziej ewidentne, w języku niemieckim skłaniamy się do personalizacji pozycji. Uzasadnić można to jedynie specyfiką języka potocznego, a nie - argumentami rzeczowymi ${ }^{23}$ (SP237).

(20) Słowa stosowane w wojsku, które określają stopnie wojskowe, mają wszystkie rodzaj gramatyczny, $\mathrm{i}$ to jest rodzaj męski. To nie ma nic wspólnego z płcią osoby, która nosi dany stopień wojskowy ${ }^{24}$ (SP417).

Dla niektórych ma to daleko idące konsekwencje pozwalające na stwierdzenia dotyczące statusu gramatycznego SW.

(21) Nazwy stopni wojskowych nie są rzeczownikami i dlatego nie mają rodzaju²5 (SP195).

(22) Wiele stopni wojskowych brzmi tak czy tak neutralnie: ,,pani sierżant”, ,pan sierżant”, ,,pani porucznik”, ,pan porucznik”, nie znajduję powodu, aby kreować formy żeńskie [...] Nazwisk w niemieckim też nie oznaczamy według płci ${ }^{26}$ (SP6).

${ }^{23}$ „Ob es irgendwann mal verstanden wird. Die Berufs oder Rangbezeichnung stellt eine ROLLE dar. Diese wird nur durch eine Person besetzt. Aufgabe der Rolle ist die damit verbundene Tätigkeit zu beschreiben, nicht das Geschlecht der besetzenden Person. In anderen Sprachen ist dies oft eindeutiger, im deutschen neigt man zum personalisieren der Rolle. Dies ist jedoch eher umgangssprachlich als sachlich zu begründen”.

${ }^{24}$ „Die militärischen Begriffe, welche einen Dienstrang bezeichnen haben alle ein grammattisches Geschlecht, welches männlich ist. Dies hat mit dem Geschlecht der Person, welche einen Dienstgrad ausübt überhaupt nichts zu tun".

${ }^{25}$ „Dienstgradbezeichnungen sind keine Substantive und haben daher auch kein Geschlecht”.

${ }^{26}$ „Nach meiner Erinnerung war es neben dem blöden Klang (Leutnantin, Feldwebelin) auch die Absurdität (Hauptfrau) und gerade der Wunsch nach einheitlicher Wahrnehmung. Viele Dienstgrade sind ja klanglich sowieso neutral: Frau Feldwebel, Herr Feldwebel, Frau Leutnant, Herr Leutnant, es wurde kein 
Inne wypowiedzi internautów nawiązują wprost do funkcji deiktycznej SW. Zadaniem SW jest jednoznaczne wskazywanie rozmówcy, w celu zagwarantowania skutecznej i szybkiej komunikacji. Staje się to możliwe pod warunkiem zachowania jednej formy SW, dobrze znanej członkom wspólnoty. Tworzenie nowych wariantów SW mogłoby zwłaszcza w komunikacji na polu walki - zakłócić właściwy odbiór komunikatu przez osoby, do których został on skierowany, i uniemożliwić im odpowiednie działanie.

(23) No tak, trzeba jeszcze móc wypowiedzieć stopnie wojskowe, a one muszą być jednoznacznie identyfikowalne. Jeśli jednak stopień wojskowy ma wiele ekwiwalentów, będzie to naprawdę trudne ${ }^{27}$ (SP15).

(24) 1. Stopnie wojskowe są co do zasady neutralne ze względu na płeć.

2. Język armii jest krótki, zwięzły, prosty i jasny.

Przede wszystkim podczas walki bardzo ważne jest, aby komunikacja była szybka i jasna. Dlatego dyskusja o feminizacji stopni jest zbędna ${ }^{28}(Z 127)$.

Jedną z praktyk powszechnych w komunikacji wojskowej i zapewniających szybkość oraz sprawność komunikacji codziennej jest stosowanie uznanych zwyczajowo, łatwo identyfikowalnych skrótów SW. Zdaniem respondentów wprowadzenie żeńskich SW wymusiłoby także zmianę stosowanych rozwiązań skrótowych, które miałyby dłuższą formę od obecnej, gdyż trzeba byłoby konsekwentnie dodać wykładnik żeńskości. Przez to brzmiałyby one obco (dziwnie), stałyby się trudne do wymówienia i wydłużałyby czas komunikacji, a samo identyfikowanie adresata okazałoby się trudniejsze, mniej jednoznaczne.

(25) Koleżeński skrót „Kaleu ${ }^{29 ”}$ w stosunku do koleżanek wyjdzie z użycia... Formę Kaleu'in uznałabym osobiście za obrazę. [...] Czy określenia używane na okrętach wojennych też będą dopasowane do tych nowych trendów? Czy to będzie „SEO'in”? „Oficerka operacyjna”? „SOPO'in” lub „WLO'in”? „Oficerka odpowiedzialna za kontrolę uzbrojenia?”,

Grund gesehen, hier eine weibliche Form zu kreieren [...]. Nachnamen werden im Deutschen ja auch nicht gegendert;-)".

${ }^{27}$ „Naja, man muss die Dienstgradbezeichnungen ja auch aussprechen können und sie müssen eindeutig zu verstehen sein. Wenn dann jeder Dienstgrad mehrere Äquivalente besitzt, wirds echt schwierig”.

${ }^{28}, 1$. Dienstgrade sind grundsätzlich geschlechtsneutral.

2. Die Sprache beim Militär ist kurz, knapp, einfach und klar. Vor allem in einem Gefecht ist es sehr wichtig, das die Kommunikation schnell und klar ist. Damit ist eine Diskussion über Gendern der Dienstgrade überflüssig".

${ }^{29}$ Forma Kaleu jest - stosowanym przede wszystkim w komunikacji potocznej - skrótem stopnia wojskowego Marynarki Federalnej (Bundesmarine) Kapitänleutnat.

${ }^{30}$ „Die kameradschaftliche Abkürzung Kaleu ist somit für meine weiblichen Kamerad(inn)en vorbei.... Kaleu'in würde ich als persönliche Beleidigung auffassen. [...] Werden dann auch die Bezeichnungen an 


\section{PODSUMOWANIE}

Zmiany zachodzące $\mathrm{w}$ języku wymagają ich akceptacji ze strony użytkowników, nawet w przypadku środowisk, w których każdy aspekt wspólnotowego życia odgórnie regulują przepisy. Wykorzystanie regulaminów do ustalania obowiązkowego sposobu zwracania się do siebie pozwala, przynajmniej w teorii, na przeprowadzanie szybkich zmian w rutynach językowych oraz na narzucenie tych nowych rozwiązań przez wąską grupę decydentów wszystkim osobom podlegających zapisom regulaminowym, nawet bez poddawania tych zmian pod dyskusję lub konsultacje. Jednak - jak pokazuje interesująca nas dyskusja w Niemczech - silny głos nieformalnego protestu (ministerstwo obrony nie prowadziło formalnych konsultacji) wobec planów zmian rutyn językowych w wojsku doprowadził do szybkiej rezygnacji z tego przedsięwzięcia. I użytkownicy języka, i jego badacze wiedzą, jak silne okazują się przyzwyczajenia w stosowaniu przyswojonych skryptów zachowań. Zmianę wprowadzoną odgórnie wbrew większości użytkowników, nawet $\mathrm{w}$ środowisku tak restrykcyjnym i stosującym się do regulaminów, przeprowadza się bardzo trudno. Zachowania językowe, nawet te najbardziej sformalizowane, muszą zatem przejść ewolucję w języku, a użytkownicy potrzebują czasu, aby się do nich przyzwyczaić, przekonać, tak aby w końcu je zaakceptować.

Trudno dzisiaj prognozować, jakie będą dalsze losy feminizacji SW w Bundeswerze. Należy się zastanowić, czy trzyetapowy scenariusz wprowadzania feminatywów do socjolektów, opisany przez Pusch (1985) i Jaworskiego (1998), może zrealizować się w niemieckim środowisku wojskowym. Zgodnie z tą koncepcją, w pierwszym etapie $\mathrm{w}$ danym socjolekcie nie występują rzeczowniki tytularne rodzaju żeńskiego z powodu braku kobiet we wspólnocie komunikatywnej. Ten etap Bundeswera ma już za sobą. W następnym do dotychczasowego wyłącznie męskiego środowiska wchodzą nieliczne kobiety i to one postulują - jak miało to miejsce $\mathrm{w}$ analizowanej dyskusji - pozostawienie nazw męskich na określenie swych zawodów lub funkcji, gdyż wiąże się to w ocenie społecznej z zachowaniem prestiżu danego zawodu. Dla kolejnego charakterystyczne okazuje się coraz większe otwarcie danego zawodu na kobiety, z czasem dochodzi we wspólnocie do zbalansowania grupy kobiet i mężczyzn. Wtedy pojawiają się feminatywy zyskujące coraz większą akceptację społeczną, także akceptację samych zainteresowanych. Taki rozwój sytuacji w wojsku zależy od wielu czynników. Po pierwsze - od większego udziału kobiet w siłach zbrojnych (niektórzy politycy niemieccy mówią o dążeniu do osiągnięcia poziomu $30 \%$ ), ale także od postępującej akceptacji społecznej dla feminatywów w różnych innych obszarach życia społecznego. Tymczasem jest to temat budzący nadal duże emocje społeczne i przedmiot intensywnych sporów. Jednak znaczenie decydujące należy przypisać występowaniu czynników specyficznych dla samego socjolektu, a obecnie to właśnie one silnie hamują omawiany proces. Są nimi przede wszystkim społeczne postrzeganie wojska jako domeny tradycyjnie męskiej oraz

Board dem derzeitigen Trend angepasst? Wäre man dann die SEO'in? Seeeinsatzoffizierin? Die SOPO'in oder auch die WLO'in? Waffenleitoffizierin?" 
hermetycznej i mało podatnej na zmiany, co przekłada się na językowo-komunikacyjną specyfikę struktur socjolektalnych, a także na realizację najistotniejszych funkcji komunikacyjnych form adresatywnych.

\section{BIBLIOGRAFIA}

Bąk, P. 2010. „Berufliche Frauenbezeichnungen oder weibliche Berufsbezeichnugen? Möglichkeiten und Grenzen der Erfassung von Äquivalenzen im Bereich des Polnischen und Deutschen”. W Text und Stil, red. Z. Bilutlewicz. Frankfurt am Main - Berlin - New York: Peter Lang, 355-369.

Bąk, P. 2013. „Poprawność polityczna a problem ekwiwalencji polskich i niemieckich żeńskich nazw osobowych". Lingwistyka Stosowana. Applied Linguistics. Angewandte Linguistik 8: $27-41$.

Carreiras, H., i G. Kümmel. 2008. Women in the Military and in Armed Conflict. Wiesbaden: Springer VS.

Cieszkowski, M. 2015. „Zum geschlechtergeregelten Sprachgebrauch am Beispiel deutscher und polnischer Stellenausschreibungen”. Linguistik Online 70 (1): 23-42.

Dargiewicz, A. 2021. „Ist das Polnische eine geschlechtergeregelte Sprache? Zur Movierung im Polnischen”. Prace Językoznawcze 23 (1): 179-198.

Diewald, G., i A. Steinhauer. 2020. Handbuch geschlechtergerechte Sprache. Berlin: Duden.

Grabias, S. 2019. Język w zachowaniach społecznych, wyd. 10 popr. Lublin: Wydawnictwo Uniwersytetu Marii Curie-Skłodowskiej.

Jaworski, A. 1989. „On gender and sex in Polish”. International Journal of the Socjology of Langugage 78: 83-92.

Kołodziejek, E. 2010. „Społeczne i kulturowe uwarunkowania współczesnych odmian zawodowych (na przykładzie profesjolektów marynarzy, żołnierzy i policjantów)". W O językach zawodowych i środowiskowych. Materiaty VII Forum Kultury Słowa. Gdańsk, 9-11 października 2008 roku, red. M. Milewska-Stawiany, i E. Rogowska-Cybulska. Gdańsk: Wydawnictwo Uniwersytetu Gdańskiego, 106-116.

Łaziński, M. 2006. O panach i paniach. Polskie rzeczowniki tytularne i ich asymetria rodzajowo-ptciowa. Warszawa: Wydawnictwo Naukowe PWN.

Marciniak, S. 1987. Język wojskowy. Warszawa: Ministerstwo Obrony Narodowej.

Marcinkowski, M. 2014. „Służba wojskowa jako służba wartościom”. Colloquium Wydziału Nauk Humanistycznych i Społecznych. Kwartalnik 1: 69-88.

Marcjanik, M. 2001. „Etykieta językowa”. W Współczesny język polski, red. J. Bartmiński. Lublin: Wydawnictwo Uniwersytetu Marii Curie-Skłodowskiej, 281-291.

Miodek, J. 2010. Socjolożka czy (pani) socjolog?. http://www.gazetawroclawska.pl/artykul/311691,jan-miodek-socjolozka-czy-pani-socjolog,id,t.html (dostęp: 30.11.2021).

Piekot, T. 2008. Język w grupie społecznej. Wprowadzenie do analizy socjolektu. Wałbrzych: Wydawnictwo Państwowej Wyższej Szkoły Zawodowej im. Angelusa Silesiusa.

Pusch, L.F. 1985. „Weibliche Personenbezeichnungen als Mittel weiblicher Realitätsdefinition”. W Sprachtheorie, Pragmatik, Interdisziplinäres, red. W. Kürschner, R. Vogt, i S. Siebert-Nemann. Tübingen: Niemeyer, 257-273.

Tomiczek, E. 1983. System adresatywny współczesnego języka polskiego i niemieckiego. Socjolingwistyczne studium konfrontatywne. Wrocław: Wydawnictwo Uniwersytetu Wrocławskiego. 


\title{
WYKAZ ŹRÓDEŁ
}

https://www.augengeradeaus.net (= AA) (28 lutego 2021).

https://www.bundeswehr.de (18 marca 2021).

https://www.polskiikropka.pl (29 marca 2021).

https://www.ris.bka.gv.at (12 marca 2021).

https://www.spiegel.de (= SP) (24 lutego 2021).

https://www.zeit.de (= Z) (26 lutego 2021).

\section{„Military Ranks Are not Nouns, therefore, They Cannot Be Classified by Grammatical Gender”. Sociolinguistic Aspects of the Discussion on Feminisation of Military Ranks in Germany}

Keywords: Modern German language variations, military sociolect, forms of address, military ranks, feminised forms.

\begin{abstract}
The article analyses internet comments concerning feminised forms of address triggered as a result of the discussion that took place in German media in September 2020 regarding the plans of German Federal Ministry of Defence to introduce feminised equivalents of existing military ranks. The article presents the collected research material and discusses its social and linguistic arguments that have led to the decision of not introducing top-down planned changes. The analysis deals with relevant sociolingustic aspects incl. relations that currently take place in processes both within German society and in standard language vs the development of military sociolect. Moreover, the article indicates crucial dependencies between constitutive values for military community and communicative practices of this community. Those dependencies, on the one hand, influence the choice of linguistic forms used daily in military communication and, on the other hand, determine factors that have an impact on the development of the sociolect (its linguistic forms and behavioral scripts). The article also presents historical determinants that provoke certain approach to feminised forms in the military. Furthermore, the article highlights the character of communicative community which creates the opportunity to introduce crucial changes (also in linguistic routines such as the discussed introduction of feminised equivalents of existing military ranks) in a formal, top-down manner. The conducted analysis of internet comments displays a significant linguistic awareness of military community members also related to behavioral scripts that tend to be difficult to change. The said analysis allows to define the specificity of how the addressing system functions in military sociolect and its impact on creating feminised forms of address.
\end{abstract}

